\title{
Evaluation of Anti-oxidant and Anti-diabetic Activity of Flower Extract of Clitoria ternatea L
}

\author{
Manivannan Rajamanickam*, Prabakaran Kalaivanan, Ilayaraja Sivagnanam \\ Department of Chemistry, Government Arts College (Autonomous), Kumbakonam, Tamilnadu, India.
}

\author{
ARTICLE INFO \\ Article history: \\ Received on: 12/02/2015 \\ Revised on: 16/04/2015 \\ Accepted on: 06/06/2015 \\ Available online: 28/08/2015 \\ Key words: \\ Clitoria ternatea, GC-MS \\ analysis, blood glucose level, \\ biochemical estimation.
}

\begin{abstract}
Clitoria ternatea belonging to the family Fabaceae, commonly known as Butterfly pea. A wide range of secondary metabolites including triterpenoids, flavonol glycosides, anthocyanins and steroids were isolated from Clitoria ternatea Linn. GC-MS analyses of $\mathrm{CHCl}_{3}$ and EtOAc fractions were performed on Gas Chromatography with mass spectrometer. The aim of the present study was to evaluate the radical scavenging ability, using the stable radical DPPH and anti-diabetic activity in alloxan induced diabetes in albino rats was evaluated from the flowers extract of Clitoria ternatea. The blood glucose level in the different groups was assayed and biochemical parameters were assessed to support the proposed hypothesis. During the experimental period, body weight of all the rats was determined at regular intervals of time. The serum glucose lowering activity was compared with glibenclamide, a standard hypoglycemic drug.
\end{abstract}

\section{INTRODUCTION}

Normally, the body produces and processes insulin to rise in glucose levels but in diabetes, this process does not occur and the glucose levels normally high. Alloxan is one of the usual substances used for induction of diabetes mellitus apart from streptozotocin and was a destructive effect on the beta $(\beta)$ cells of the pancreas as previously reported (Jelodar et al., 2003). The ethanomedicals approach seems likely to increase the possibility of discovering new drugs for the management of Type-II diabetes mellitus (Payne, 2001). World ethanobotanical information about it is a big challenge to fully exploit medicinal biodiversity to look for phytochemicals with insulin mimetic property (AlarconAguilar et al., 1998). Clitoria ternatea belonging to the family Fabaceae, commonly known as Butterfly pea. It is a perennial twinning herb with blue and white flowers (Aruna et al., 1999). C. ternatea is widely used in the treatment of chronic bronchitis, dropsy, goiter, leprosy, mucous disorders, sight weakness, skin diseases, sore throat and tumors. It was used traditionally to cure

* Corresponding Author

Manivannan - Rajamanickam, Assistant Professor, Department of Chemistry, Government Arts College (Autonomous), Kumbakonam, Tamilnadu, India.Email: manickam_mani@yahoo.co.in sexual ailments, like infertility and gonorrhea, to control menstrual discharge and also as an aphrodisiac (Reid and Sinclair, 1980). Its extracts possess a wide range of pharmacological activities including anti-microbial, anti-pyretic, anti-inflammatory, analgesic, diuretic, local anesthetic, anti-diabetic, insecticidal, blood platelet aggregation inhibiting and for use as a vascular smooth muscle relaxing properties (Mukherjee et al., 2008; Anand et al., 2011). Based on this aspect, we were selected the plants Clitoria ternatea Linn for treatment of diabetes mellitus. This study is designed to extract the phytochemical constituents of the flowers of this plant and to study its effect of antioxidant and antidiabetic activity on blood glucose and biochemical parameters was assessed to support the proposed hypothesis.

\section{MATERIALS AND METHODS}

\section{Plant Materials}

The beautiful blue flowers of Clitoria ternatea, an ornamental plant, was collected during March - April from a family garden of houses in and around Kumbakonam and the plant was taxonomically identified by Dr. N. Ramakrishnan, Associate Professor \& Head, Department of Botany, Government Arts College (Autonomous), Kumbakonam, Tamilnadu, India. 
The flowers materials were dried at room temperature. The voucher specimen (GACBOT - 121) was maintained in our research laboratory for future reference. The plant material was shade-dried with occasional shifting and stored in an air - tight container.

\section{Extraction methods}

The air dried flowers of $C$. ternatea $(750 \mathrm{~g})$ was extracted three times (6 days each) with $95 \% \mathrm{MeOH}(4 \mathrm{X} 500$ $\mathrm{mL})$ at room temperature $\left(30 \pm 2{ }^{\circ} \mathrm{C}\right)$. The combined methanolic extract was evaporated in vaccuo. Before going to fractionation, so it draws our attention to do the sequential partition fraction of methanol crude extract $(30.7 \mathrm{~g})$. The resulting methanolic extract residue was suspended in hot water $(1000 \mathrm{~mL})$ and extracted successively partitioned with $\mathrm{CHCl}_{3}$ and EtOAc and the solvent recovered by simple distillation. Evaporation of the solvent under reduced pressure gave the crude extract $\mathrm{CHCl}_{3}(27.0 \mathrm{~g})$ and EtOAc $(24.5 \mathrm{~g})$ respectively.

\section{GC-MS analysis}

GC-MS analysis of $\mathrm{CHCl}_{3}$ and EtOAc extracts were performed on a Hewlett Packard HP 6890 Gas Chromatography with Hewlett Packard 5973 mass spectrometer system equipped with a DB-5 capillary column $(30 \mathrm{~m} \times 0.25 \mathrm{~mm}$ id, film thickness $0.25 \mu \mathrm{m})$. The oven temperature was programmed from $70-240^{\circ} \mathrm{C}$ at the rate of $5^{\circ} \mathrm{C} / \mathrm{min}$. The ion source was set at $240{ }^{\circ} \mathrm{C}$ and electron ionization at $70 \mathrm{eV}$. Helium used as the carrier gas at a flow rate of $1 \mathrm{~mL} / \mathrm{min}$. Scanning range was 35 to $425 \mathrm{amu}$. Interpretation of the mass spectrum of the unknown part was compared with the spectrum of the known components stored in the NIST library. The name, molecular weight and structure of the components of the test materials were found out.

\section{ANTI-OXIDANT ACTIVITIES}

\section{DPPH free radical scavenging test}

The DPPH is a stable free radical, which was widely accepted as a tool for estimating free radical-scavenging of s.15 Hydrogen or electron donation capacities of the compounds were measured from the bleaching of the purple-colored methanol solution of 1, 1-diphenyl-2-picrylhydrazyl (DPPH). This spectrophotometer test uses the stable radical DPPH as a reagent. The sample solution of material $(50 \mu \mathrm{L})$ at four concentrations (1.0, $0.5,0.25$ and $0.125 \mathrm{mg} / \mathrm{mL}$ ) was mixed with freshly prepared methanolic solution of DPPH $(634 \mu \mathrm{M})$ and allowed to stand for $30 \mathrm{~min}$ at room temperature. The absorbance was measured at $515 \mathrm{~nm}$ using a spectrophotometer and inhibits free radical DPPH in percent $(\%)$ was calculated using the formula below:

The percent of inhibition of DPPH reduction (decolourization)

$$
\% \text { of inhibition }=\frac{\mathrm{A} 0-\text { Asample }}{\mathrm{A} 0} \times 100
$$

where $\left(\mathrm{A}_{0}\right)$ is absorbance of control (blank) and $\left(\mathrm{A}_{\text {sample }}\right)$ is absorbance of test compound. The compound concentration showing $50 \%$ inhibition $\left(\mathrm{IC}_{50}\right)$ was calculated from the plot of inhibition percentage against sample concentration. Tests were carried out in triplicate. Samples and DPPH dissolved in methanol. L-ascorbic acid was used as positive control.

\section{ANTI-DIABETIC STUDY}

\section{Animals}

Male albino rats (200 - $250 \mathrm{~g})$ of Wistar strain was procured from the animal house, Department of Zoology, Government Arts College (Autonomous), Bharathidasan University, Kumbakonam, Tamilnadu, India. Animals were fasted overnight and was divided into different test groups each consisting of six animals. They housed in cages and maintained under standard conditions at $26 \pm 2{ }^{\circ} \mathrm{C}$ and relative humidity 60 $65 \%$ and $12 \mathrm{~h}$ light and $14 \mathrm{~h}$ dark cycles each day for one week before and during the experiments. All animals were fed with the standard rodent pellet diet, and water adlibitum. Before starting the experiment on animals, the experimental protocol was subjected to the scrutiny of the Institutional Animal Ethics Committee (IAEC), Bharathidasan University, Trichirappalli, Tamilnadu, India (Approval No. BDU/IAEC/2011/31/29.03.2011).

\section{Experimental Design}

The animals were divided into six groups each containing six animals.

Group-I: Served as normal control. Control rats received only normal saline.

Group-II: The Second group of rats with diabetes was induced by intraperitoneal injection of alloxan for 2 days.

Group-III: Alloxan treated rats was administered the Glibenclamide (10 mg / kg) and served as standard.

Group-IV: Alloxan treated rats was administered the $\mathrm{CHCl}_{3}$ extract (300 mg / kg)

Group-V: Alloxan treated rats was administered the ethyl acetate extract (300 mg / kg)

Group-VI: Alloxan treated rats were administered the methanolic extract (300 mg / kg)

After the treatment period all the groups of rats were euthanized by anesthesia using chloroform vapor and the rats was sacrificed by decapitation. Then the blood was collected in a tube for analysis.

\section{Evaluation of Anti-diabetic Activity}

Before starting the experiment, animals were separated according to their body weight. The animals were injected intraperitoneally with freshly prepared alloxan monohydrate (150 $\mathrm{mg} / \mathrm{kg}$ ) in normal saline solution. Alloxan administration resulted in significant elevation of glucose level and reduction in body weight. Diabetes was confirmed by the elevated blood glucose levels determined at $72 \mathrm{~h}$. The blood sugar level was measured by digital display glucometer (One touch - Johnson \& Johnson Ltd.). Initial blood samples were taken before the oral administration of the standard drug glibenclamide and plant extracts at doses of 300 $\mathrm{mg} / \mathrm{kg}$. The blood glucose level test was done on the normal, 
diabetic and treated diabetic rats were measured at $0,4,8$ and 12 days after oral administration of Glibenclamide and different extracts.

\section{Biochemical Analysis}

At the end of the experimental period (12 days), the rats were anesthetized with chloroform following a 12 hour fast. Blood samples were drawn by cardiac puncture into plain tubes. The blood samples were centrifuged at $3500 \mathrm{rpm}$ for 20 minutes using a refrigerated centrifuge at $4^{\circ} \mathrm{C}$ (Remi Laboratory Instruments, Mumbai, India). The serum collected was stored at $-20^{\circ} \mathrm{C}$ until needed. Serum albumin was determined using the bromcresol green method with an autopak kit. The total protein present in serum was estimated by the Biuret method (Fawcett and Scott, 1960) using an autopak kit. Serum was separated and analyzed for serum cholesterol (Roeschlau et al., 1974), serum triglycerides by enzymatic DHBS colorimetric method (Muller et al., 1977), serum HDL (Allain et al., 1974), serum LDL (Friedewald et al., 1972), serum creatinine (Bowers, 1980), serum urea (Wilson, 1966) and levels of hemoglobin was estimated using the ion exchange resin method with kits purchased from Diotek India Ltd, Mumbai, India (Trinder, 1969). To the animals, standard drug glibenclamide (10 $\mathrm{mg} / \mathrm{kg}$ orally) and the test plant extract (300 mg / kg orally) were administered by dissolving in $2 \%$ Twen-80 / water and normal saline respectively.

\section{Acute Toxicity Studies}

Acute toxicity studies were carried out according to the literature (Ghosh, 2005). Animals of either sex were fasted for eighteen hours and used. A dose of $300 \mathrm{mg} / \mathrm{kg}$ methanolic, chloroform and ethyl acetate extracts from our selected plant was administrated orally to 12 rats, additionally three rats were kept as control. The control group received distilled water. Then they were observed for 72 hours. Since no mortality was observed and the behavioral pattern unaffected. No depth was observed at the end of the study.

\section{Statistical Analysis}

All experiments were reported as means \pm SD. Significant differences for multiple comparisons was determined by one-way analysis of variance (ANOVA) followed by Duncan test with $\mathrm{p}$ value less than 0.05 which was considered as statistically significant.

\section{RESULTS AND DISCUSSION}

\section{Chemical constituents}

The active principles with their retention time (RT), molecular formula, molecular weight (MW), components present in the chloroform and ethyl acetate fraction of Clitoria ternatea flowers were identified by GC-MS analysis (Figure $1 \& 2$ ). The GC-MS spectrums of $\mathrm{CHCl}_{3}$ extracts showed a molecular ion peak at $\mathrm{m} / \mathrm{e} 312.97,262.73,239.67,264.75$ and follow a molecular formulas of $\mathrm{C}_{18} \mathrm{H}_{19} \mathrm{NO}_{4}$ (MW 313.00), $\mathrm{C}_{21} \mathrm{H}_{38} \mathrm{O}_{4}$ (MW 262.00), $\mathrm{C}_{35} \mathrm{H}_{68} \mathrm{O}_{4}$ (MW 239.00), $\mathrm{C}_{21} \mathrm{H}=\mathrm{O}_{4}(\mathrm{MW} 264.00)$ and EtOAc extract showed a molecular ion peak at $\mathrm{m} / \mathrm{e} 87.144,264.76$, 298.91, 71.19 and follow a molecular formulas of $\mathrm{C}_{14} \mathrm{H}_{28} \mathrm{O}_{2}(\mathrm{MW}$ 87.00), $\mathrm{C}_{19} \mathrm{H}_{36} \mathrm{O}_{2}$ (MW 264.00), $\mathrm{C}_{25} \mathrm{H}_{42} \mathrm{O}_{2}$ (MW 298.00), $\mathrm{C}_{16} \mathrm{H}_{30} \mathrm{O}_{2}$ (MW 71.00).

Based on GCMS analysis we were identified four compounds in the chloroform extract namely (1) Cephalotaxine, 3deoxy, 3, 11- epoxy (3a, 11a) (RT 19.5), (2) 9, 12 octadecadienoic acid [z, z], 2- hydroxy- 1- [hydroxy methyl] ethyl ester (RT 22.0), (3) Hexa decanoic acid, 1-[hydroxymethyl]- 1, 2 ethanediyl ester (RT 23.2) (4) 9- octadecanoic acid [z]-2- hydroxy1- [hydroxy methyl] ethyl ester (25.88) and another four compounds was identified in the ethyl acetate extract namely (1) Dodecanoic acid, 10- methyl- methyl ester (RT 16.9), (2) 10octadecanoic acid, methyl ester (RT 18.63), (3) Cyclopropane butanoic acid, 2- [[2-[[2-[[2-pentyl cyclopropyl] methyl] cyclopropyl] methyl] cyclopropyl] methyl]- methyl ester (RT 18.85 (4) 1, 2-15, 16-Diepoxy hexadecane (RT 22.0).

Table 1: DPPH free radical scavenging activity of the flower extracts of Clitoria ternatea white extracts.

\begin{tabular}{|c|c|c|c|c|c|}
\hline Concentration (mg / ml) & & & $0(\mu \mathrm{g} / \mathrm{ml})$ & & \\
\hline \multirow[t]{2}{*}{ Samples } & $\mathbf{1 . 0}$ & 0.5 & 0.25 & 0.125 & $\mathbf{I C}_{50}$ \\
\hline & \multicolumn{5}{|c|}{ Radical scavenging effect $(\%)$} \\
\hline Clitoria ternatea chloroform extract & $92.46 \pm 0.05$ & $88.42 \pm 0.04$ & $80.94 \pm 0.01$ & $76.79 \pm 0.02$ & $132.50 \pm 0.06$ \\
\hline Clitoria ternatea ethyl acetate extract & $88.79 \pm 0.20$ & $83.91 \pm 0.01$ & $77.88 \pm 0.50$ & $66.05 \pm 0.04$ & $107.42 \pm 0.02$ \\
\hline Clitoria ternatea methanol extract & $85.27 \pm 0.02$ & $77.68 \pm 0.60$ & $74.51 \pm 0.01$ & $56.12 \pm 0.05$ & $95.30 \pm 0.10$ \\
\hline L-ascorbic acid & $99.05 \pm 0.01$ & $96.89 \pm 0.20$ & $95.12 \pm 0.04$ & $90.64 \pm 0.10$ & $70.80 \pm 0.02$ \\
\hline
\end{tabular}

Values are expressed in Mean \pm Standard Deviation $(\mathrm{M} \pm \mathrm{SD})$

Table 2: Effect of Solvent Extracts from Clitoria ternatea on fasting blood glucose level in alloxan induced diabetic rats

\begin{tabular}{|c|c|c|c|c|c|}
\hline \multirow[t]{2}{*}{ Group } & \multirow[t]{2}{*}{ Treatment } & \multicolumn{4}{|c|}{ Fasting blood glucose level (mg / dI) } \\
\hline & & Initial & $4^{\text {th }}$ day & $8^{\text {th }}$ day & $12^{\text {th }}$ day \\
\hline I & Normal Control & $97.67 \pm 5.62$ & $91.67 \pm 3.79$ & $97.67 \pm 3.79$ & $94.33 \pm 2.52$ \\
\hline II & Diabetic Control & $388.67 \pm 6.11$ & $401.67 \pm 3.51$ & $405.67 \pm 2.08$ & $411.33 \pm 2.52$ \\
\hline III & Glibenclamide(10 mg / kg) & $374.33 \pm 4.04$ & $342.33 \pm 2.52$ & $273.33 \pm 4.04$ & $152.00 \pm 4.58$ \\
\hline IV & Chloroform Extract (300 mg / kg) & $378.33 \pm 3.51$ & $255.67 \pm 4.04$ & $192.00 \pm 5.29$ & $136.33 \pm 5.51$ \\
\hline $\mathrm{V}$ & Ethyl acetate Extract $(300 \mathrm{mg} / \mathrm{kg})$ & $385.67 \pm 4.51$ & $287.33 \pm 11.02$ & $213.00 \pm 7.21$ & $169.67 \pm 4.73$ \\
\hline VI & Methanolic Extract $(300 \mathrm{mg} / \mathrm{kg})$ & $382.43 \pm 4.11$ & $292.63 \pm 3.92$ & $219.00 \pm 4.10$ & $171.42 \pm 4.41$ \\
\hline
\end{tabular}

Alloxan monohydrate $(120 \mathrm{mg} / \mathrm{kg})$ was used as a diabetogen.

Values are expressed in Mean \pm Standard Deviation $(n=6)$

Superscript letters represent $P<0.05$ (Duncan test). Group II compared with Group III, IV and V. 

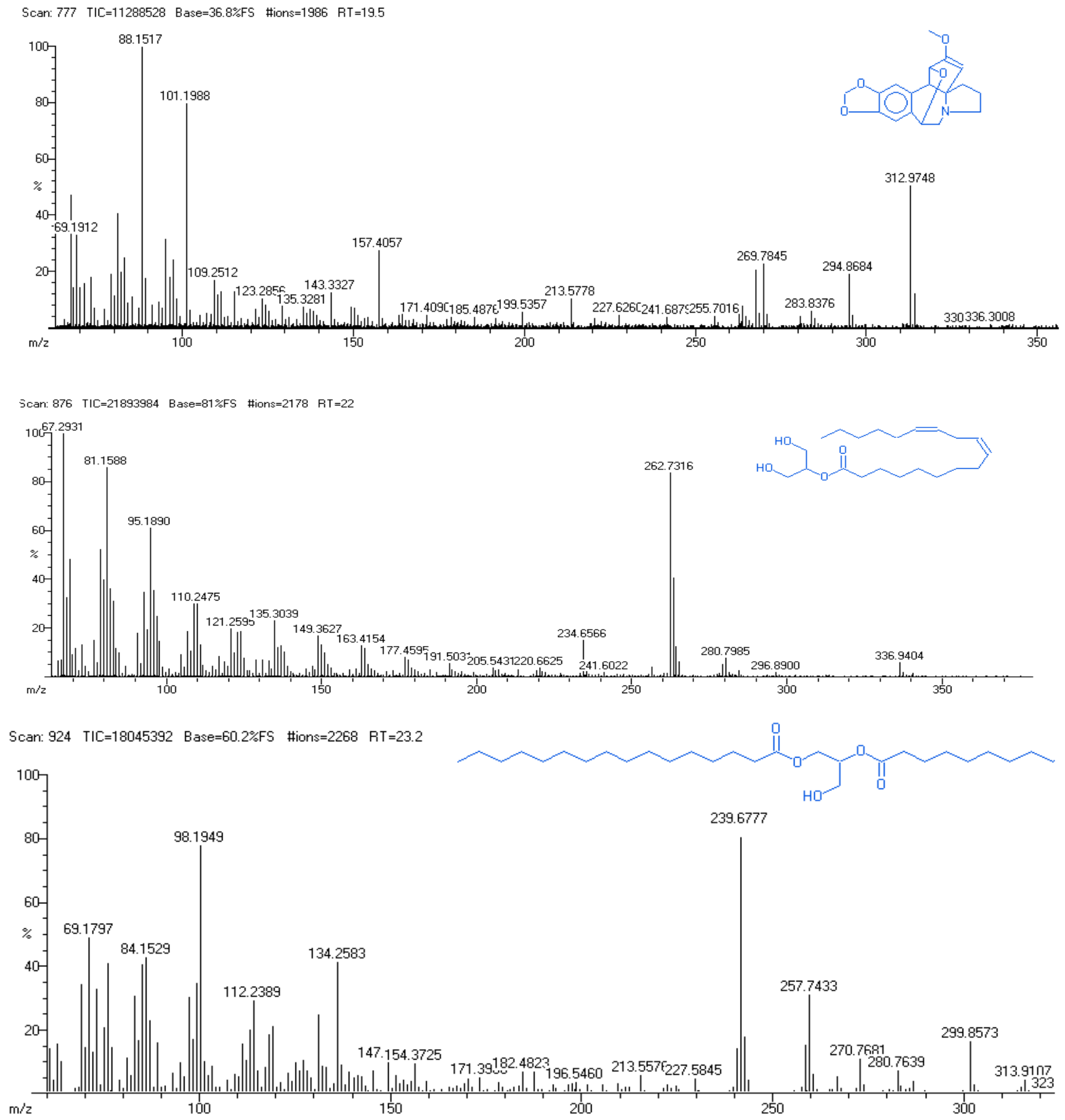

Scan: $10 \Xi 1$ TIC $=2753232]$ Base $=\{1.6 \%$ FS Hion $s=2219$ RT $=25.88$

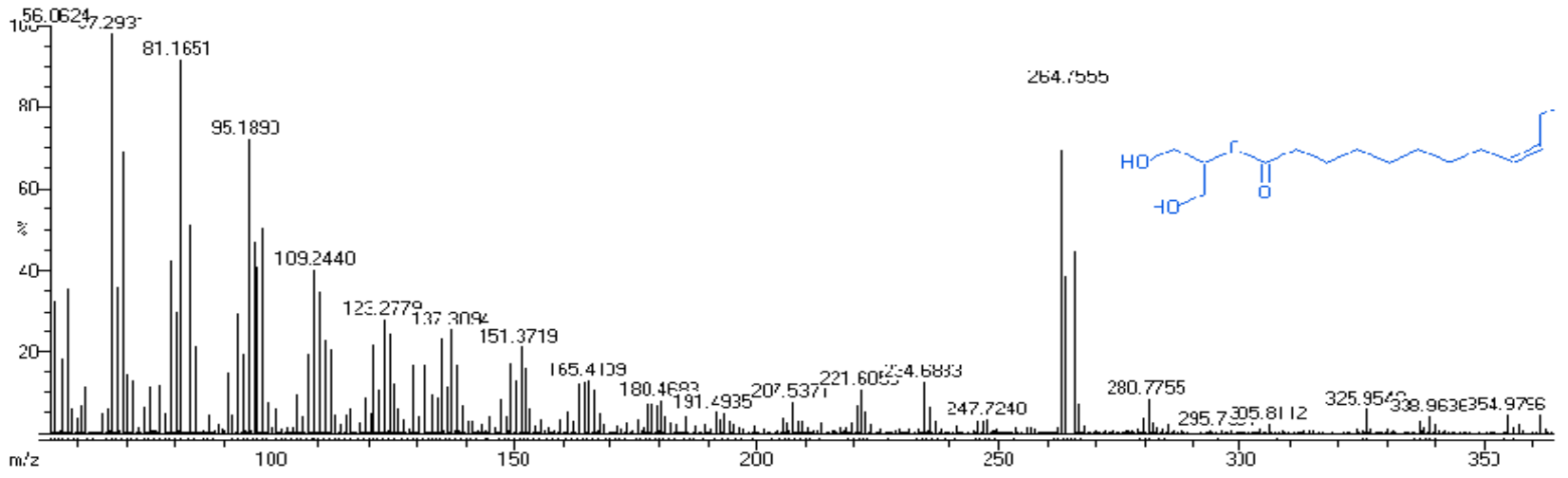

Fig. 1: GC-MS identification of compounds present in $\mathrm{CHCl}_{3}$ extract of Clitoria ternatea 


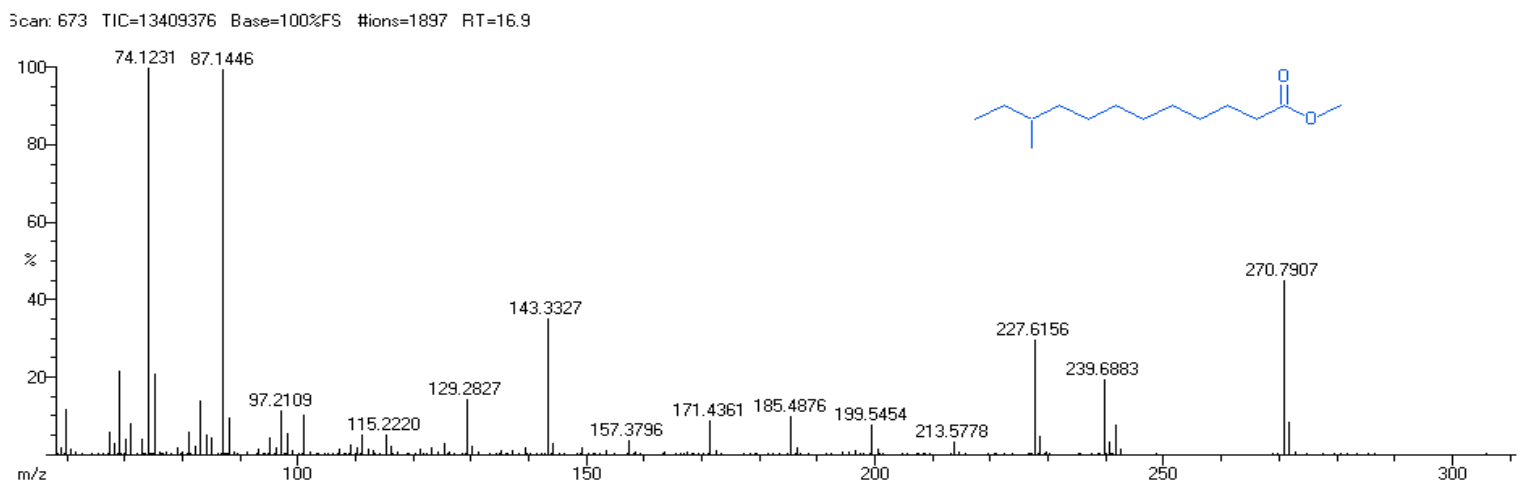

Scan: 742 TIC $=39436848$ Base $=100 \%$ FS \#ions $=2001$ RT $=18.63$

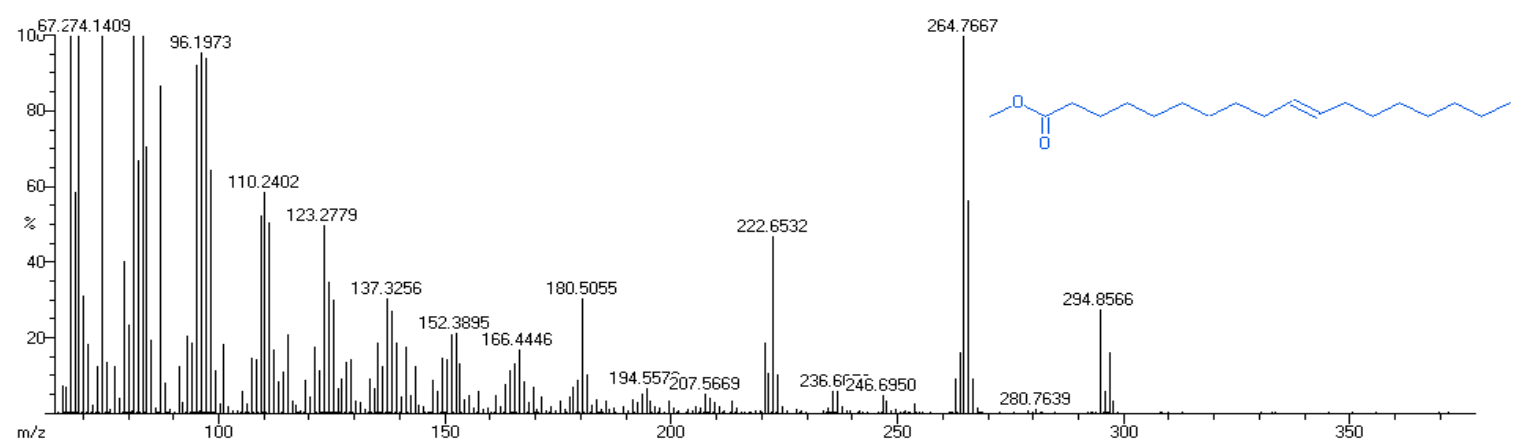

jacan: 751 TIC=10307632 Base=41.7\%FS \#ions $=2022$ RT $=18.85$

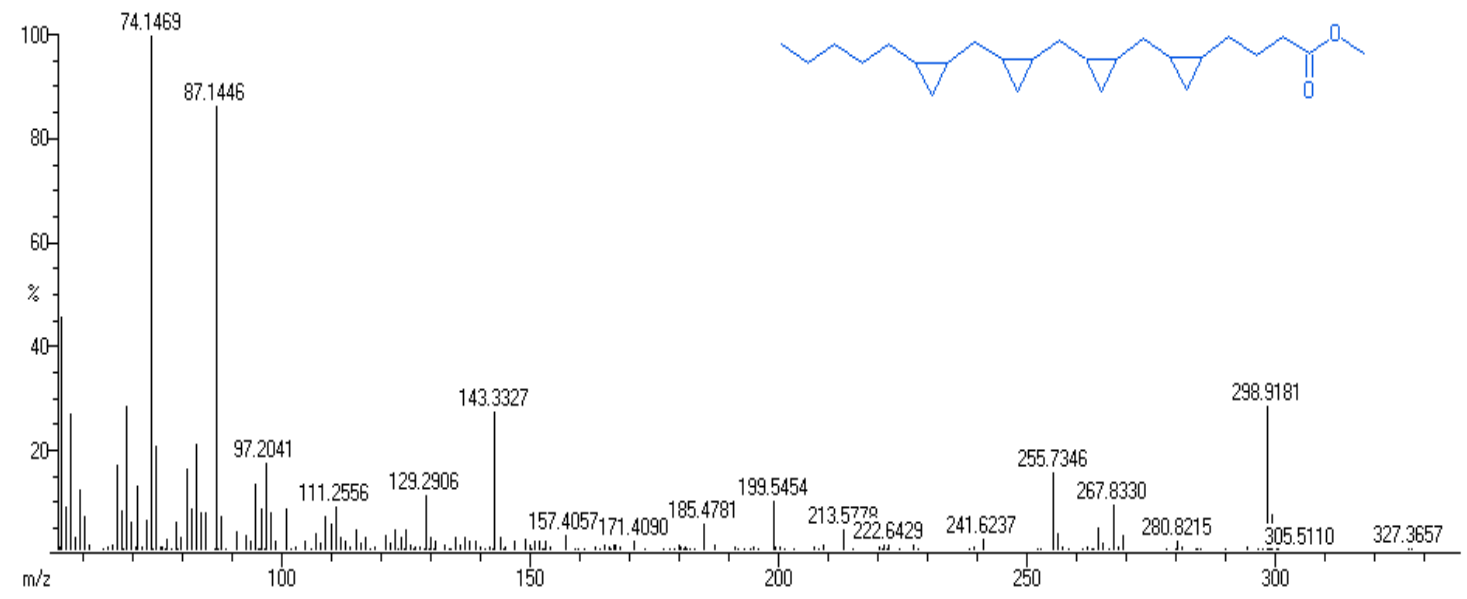

Scan: 876 TIC=11641360 Base=94.7\% FS \#ions $=2158 \quad$ RT $=22$

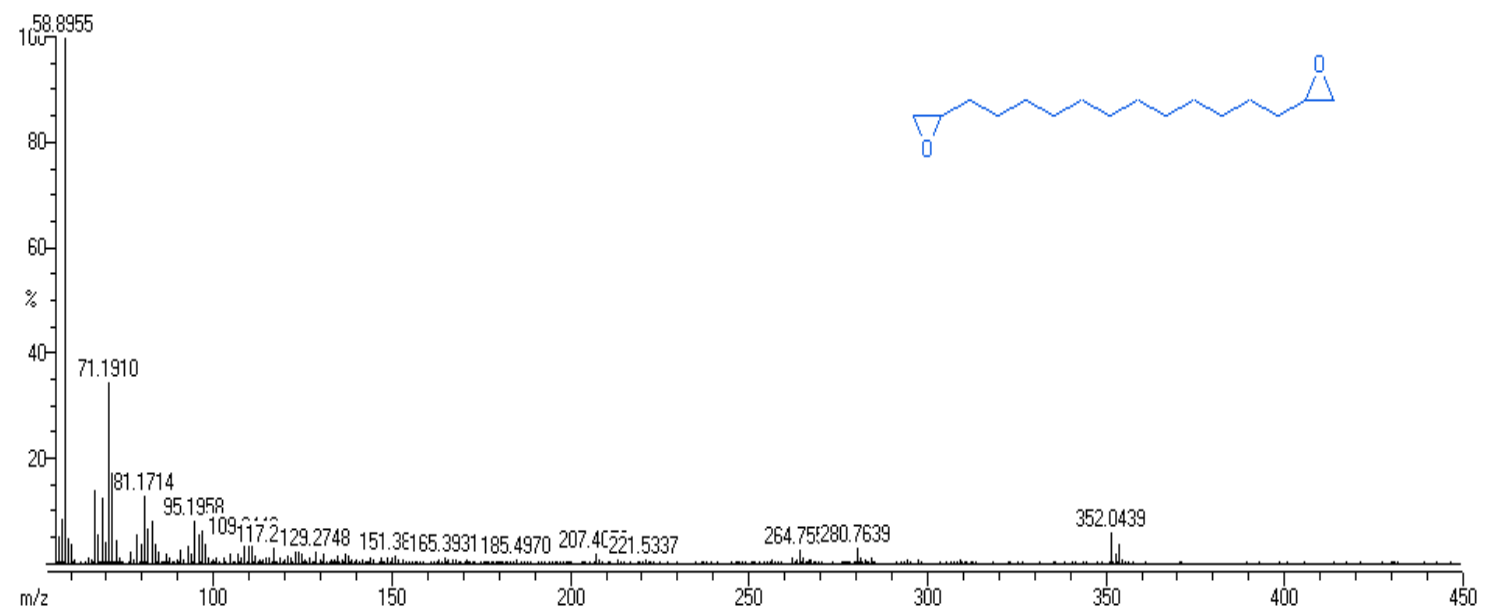

Fig. 2: GC-MS identification of compounds present in EtOAc extract of Clitoria ternatea. 


\section{Anti-oxidant activity}

The anti-oxidant activity of Clitoria ternatea flowers extract in solvents of varying polarity was measured with hydrogen granting or radical scavenging ability, using the stable radical, DPPH. The method was based on reduce alcoholic DPPH solutions in the presence of a hydrogen granting anti-oxidant. The DPPH free radical scavenging activity of the Chloroform extract of Clitoria ternatea showed the highest scavenging activity (\% inhibition $92.46,88.42,80.94$ and 76.99 at $1.0,0.5,0.25$ and 0.125 $\mathrm{mg} / \mathrm{ml}$ respectively), followed by ethyl acetate extract. Methanol extract showed least DPPH radical scavenging ability with \% inhibition 85.27, 77.68, 74.51 and 56.12 at 1.0, 0.5, 0.25 and 0.125 $\mathrm{mg} / \mathrm{ml}$ respectively.

The results of the free radical scavenging activity of Clitoria ternatea assessed by DPPH test and amount of the sample needed for $50 \%$ inhibition of free radical activity, $\mathrm{IC}_{50}$ values was summarized in Table 1. Lower $\mathrm{IC}_{50}$ value suggests higher antioxidant activity. Based on the results found the anti-oxidant activity of Clitoria ternatea methanol extract $\left(\mathrm{IC}_{50}: 95.30 \mu \mathrm{g} / \mathrm{ml}\right)$ was comparable with standard anti-oxidant of L-ascorbic acid.

\section{Anti-diabetic activity}

During the experimental period, body weight and blood glucose level of all the rats were determined at regular intervals of time. At the end of the experimental period, the rats were anaesthetized and sacrificed by cervical dislocation. Blood collected without anticoagulant was used for serum separation. The effect of the treatment with all test compounds and glibenclamide on blood glucose concentration in normal and diabetic rats after treatment was shown in a Table 2. When the administration of chloroform extract at a dose $300 \mathrm{mg} / \mathrm{kg}$ to diabetic rats showed blood glucose level decreased from 378.33 $\mathrm{mg} / \mathrm{dI}$ to $255.67 \mathrm{mg} / \mathrm{dI}$ which was found significant ( $<$ 0.01) when compared with diabetic control and ethyl acetate extract at a dose $300 \mathrm{mg} / \mathrm{kg}$ to diabetic rats showed reduction in blood glucose level from $385.67 \mathrm{mg} / \mathrm{dl}$ to $287.33 \mathrm{mg} / \mathrm{dI}$ at $4^{\text {th }}$ day.

The methanol extract at a dose $300 \mathrm{mg} / \mathrm{kg}$ also showed the decrease in blood glucose level significantly $(\mathrm{p}<0.01)$ when compared with the diabetic control groups. At the end of experiment $\left(12^{\text {th }}\right.$ day) blood glucose level was $136.33 \pm 5.51$ and $169.67 \pm 4.73 \mathrm{mg} / \mathrm{dI}$ in the diabetic rat treated with chloroform and ethyl acetate flower extract of Clitoria ternatea respectively. Whereas methanol extracts also showed significant reduction $(\mathrm{p}<$ 0.001 ) in a blood glucose level on the diabetic rat at $12^{\text {th }}$ day of the study.

Furthermore, daily treatment of all test extracts for 12 days led to dose dependent fall in blood glucose level. Maximum effect seems to rich after $12^{\text {th }}$ day of treatment and remains constant their after. From the results of the present study, it may be insulin producing cells are functioning and the stimulation of insulin release could be responsible for most of the metabolic effects. It may be suggested that the mechanism of action of plant extracts is similar to glibenclamide. The serum glucose lowering activity was compared with glibenclamide, a standard hypoglycemic drug. Glibenclamide was used for many years to treat diabetes, to stimulate insulin secretion from pancreatic beta cells (Tian et al., 1998).

The body weights of the different groups of animals were in the range of $150-250 \mathrm{Kg}$. Alloxan caused body weight reduction, which is reversed after 12 days of treatment of chloroform, ethyl acetate and methanol extracts of Clitoria ternatea. Normal healthy control was found to be stable in their bodyweight during 12 days (Table 3) but diabetic rats show reduction in bodyweight. An increase in the body weight of normal rats was observed whereas the weight of diabetic control rats decrease from day 1 to day 12 .

When administration of plant extract to diabetic rats showed a significant $(\mathrm{p}<0.01)$ increase in body weight as compared to the diabetic control group. Chloroform extract seems to be the most promising than ethyl acetate but these two extracts were less effective than glibenclamide in maintaining body weight.

\section{Biochemical Estimation}

Biochemical parameters were assessed to support the proposed hypothesis. Diabetes mellitus is a common metabolic disease characterized by increased circulating glucose concentrations. It is associated with a variety of micro vascular, macro vascular, neurological, and infectious complications, including abnormal carbohydrate, fat and protein metabolism (Goth and Eaton, 2000). Serum albumin and total protein levels were markedly decreased in the diabetic control groups were shown in Table 4.

Total protein levels were significantly decreased in rats with Alloxan induced diabetes due to increased protein catabolism (Mansour and Newairy, 2000). However, in untreated diabetic rats, serum protein and albumin levels decreased significantly compared with the control group $(\mathrm{P}<0.001)$. Administration of alloxan decreases serum albumin levels due to increased nonenzymatic glycosylation of protein (Lowry et al., 1951). Treatment of diabetic rats with chloroform and ethyl acetate extracts restored albumin to normal levels. The present study found that daily administration of a methanol, chloroform and ethyl acetate extract from Clitoria ternatea to diabetic rats gradually increased their protein levels and that the chloroform extract at a dose of $300 \mathrm{mg} / \mathrm{kg}$ were a pronounced effect on protein content.

Serum urea and creatinine levels were decreased significantly by chloroform and ethyl acetate extracts and Glibenclamide. There was an increased level of urea (38.17 \pm $0.29)$ and creatinine $(1.34 \pm 0.040)$ in the diabetic rats. Urea and creatinine which are the major nitrogenous waste products are normally low in the blood since it is excreted in the urine continuously. When the kidney fails to filter out this nitrogenous waste due to increased blood glucose level or due to kidney failure and these nitrogenous wastes get accumulated in the blood and this can lead to unconsciousness and death (Debra Manzella, 2008). 
Table 3: Effect of Solvent Extracts from Clitoria ternatea on body weight in alloxan induced diabetic rats

\begin{tabular}{|c|c|c|c|c|c|}
\hline \multirow[t]{2}{*}{ Group } & \multirow[t]{2}{*}{ Treatment } & \multicolumn{4}{|c|}{ Body weight of the animal (g) } \\
\hline & & Initial & $4^{\text {th }}$ day & $8^{\text {th }}$ day & $12^{\text {th }}$ day \\
\hline I & Normal Control & $162.67 \pm 1.53$ & $157.33 \pm 6.43$ & $152.67 \pm 2.08$ & $155.67 \pm 3.21$ \\
\hline II & Diabetic Control & $163.00 \pm 1.00$ & $143.67 \pm 2.52$ & $137.67 \pm 2.52$ & $131.33 \pm 3.06$ \\
\hline III & Glibenclamide $(10 \mathrm{mg} / \mathrm{kg})$ & $162.33 \pm 2.89$ & $147.67 \pm 4.16$ & $148.33 \pm 3.21$ & $149.00 \pm 6.25$ \\
\hline IV & Chloroform Extract (300 mg / kg) & $166.33 \pm 1.53$ & $150.00 \pm 1.00$ & $146.67 \pm 6.11$ & $153.67 \pm 2.89$ \\
\hline $\mathrm{V}$ & Ethyl acetate Extract $(300 \mathrm{mg} / \mathrm{kg})$ & $164.67 \pm 1.53$ & $153.67 \pm 1.15$ & $155.67 \pm 2.31$ & $156.00 \pm 1.00$ \\
\hline VI & Methanolic Extract $(300 \mathrm{mg} / \mathrm{kg})$ & $163.42 \pm 1.53$ & $154.32 \pm 2.16$ & $156.84 \pm 2.56$ & $155.91 \pm 3.16$ \\
\hline
\end{tabular}

Alloxan monohydrate $(120 \mathrm{mg} / \mathrm{kg})$ was used as a diabetogen.

Values are expressed in Mean \pm Standard Deviation $(\mathrm{n}=6)$

Superscript letters represent $P<0.05$ (Duncan test). Group II compared with Group III, IV and V.

Table 4: Effect of Solvent Extracts from Clitoria ternatea on $12^{\text {th }}$ day on biochemical parameters in alloxan induced diabetic rats.

\begin{tabular}{|c|c|c|c|c|c|c|c|}
\hline \multirow{2}{*}{$\begin{array}{l}\text { Biochemical } \\
\text { parameter }\end{array}$} & \multirow{2}{*}{ First Day } & \multicolumn{6}{|c|}{$12^{\text {th }}$ day $(M \pm S D)$ Treatment } \\
\hline & & $\mathbf{I}$ & II & III & IV & $\mathbf{V}$ & VI \\
\hline Haemo-globulin & $14.33 \pm 0.42$ & $15.46 \pm 0.27$ & $12.21 \pm 0.28$ & $14.64 \pm 0.39$ & $14.52 \pm 0.1$ & $13.27 \pm 0.16$ & $12.84 \pm 0.2$ \\
\hline Albumin & $3.85 \pm 0.05$ & $3.82 \pm 0.07$ & $3.16 \pm 0.05$ & $3.91 \pm 0.07$ & $3.81 \pm 0.03$ & $3.22 \pm 0.05$ & $3.18 \pm 0.05$ \\
\hline Globulin & $2.66 \pm 0.06$ & $2.61 \pm 0.04$ & $1.80 \pm 0.04$ & $2.64 \pm 0.06$ & $3.44 \pm 0.16$ & $2.60 \pm 0.03$ & $2.52 \pm 0.05$ \\
\hline Serum Urea & $26.61 \pm 0.68$ & $26.20 \pm 0.26$ & $38.60 \pm 0.53$ & $22.23 \pm 0.49$ & $38.17 \pm 0.3$ & $30.08 \pm 1.13$ & $28.36 \pm 0.2$ \\
\hline Serum Creatinine & $0.84 \pm 0.053$ & $0.83 \pm 0.025$ & $1.32 \pm 0.053$ & $0.93 \pm 0.042$ & $1.34 \pm 0.04$ & $0.63 \pm 0.042$ & $0.82 \pm 0.02$ \\
\hline Serum Cholesterol & $169.6 \pm 2.08$ & $166.33 \pm 1.53$ & $97.00 \pm 2.65$ & $141.67 \pm 2.4$ & $144.3 \pm 1.7$ & $99.67 \pm 1.53$ & $99.01 \pm 1.5$ \\
\hline Serum triglycerides & $61.97 \pm 1.00$ & $61.13 \pm 0.23$ & $41.67 \pm 1.53$ & $62.83 \pm 1.04$ & $75.00 \pm 1.0$ & $67.83 \pm 0.76$ & $61.78 \pm 0.2$ \\
\hline Serum Protein & $6.83 \pm 0.40$ & $6.32 \pm 0.10$ & $5.15 \pm 0.13$ & $4.63 \pm 0.04$ & $7.15 \pm 0.05$ & $6.25 \pm 0.17$ & $5.95 \pm 0.13$ \\
\hline HDL & $33.67 \pm 1.53$ & $34.04 \pm 0.07$ & $27.67 \pm 1.53$ & $34.80 \pm 0.72$ & $48.21 \pm 0.3$ & $36.47 \pm 0.42$ & $34.47 \pm 0.1$ \\
\hline LDL & $64.00 \pm 1.73$ & $64.50 \pm 0.50$ & $51.67 \pm 0.58$ & $57.93 \pm 0.70$ & $71.23 \pm 0.2$ & $68.20 \pm 0.26$ & $60.17 \pm 0.5$ \\
\hline
\end{tabular}

All Parameters were measured mg / dI.

Values are expressed in Mean \pm Standard Deviation $(\mathrm{n}=6)$

Superscript letters represent $P<0.05$ (Duncan test). Group II compared with Group III, IV and V. $* P<0.05$, $* * P<0.01, * * * P<0.001$.

This levels were decreased significantly $(\mathrm{p}<0.05)$ after the treatment with chloroform and ethyl acetate extracts and glibenclamide (urea: $38.17 \pm 0.29,30.08 \pm 1.13$ and $22.23 \pm 0.49$; creatinine: $1.34 \pm 0.040,0.63 \pm 0.042$ and $0.93 \pm 0.042$ respectively) when compared to the untreated diabetic rats. The decreased level of these nitrogenous wastes after the treatment suggests that the plant extract can retrieve the renal damage caused due to diabetes. To study the effect on various other parameters viz. serum lipoproteins (total cholesterol, triglycerides, lowdensity lipoprotein, and high-density lipoprotein) were estimated for all treated groups and compared against diabetic control group. Such an increase in lipid content increases the risk of coronary heart disease and atherosclerosis (Ginsberg, 1998). The serum lipid profile reached a peak in diabetic control rats, whereas the level of high-density lipoprotein decreased. After continuous treatment with the Clitoria ternatea flower extract for 12 days rats with alloxan induced diabetes showed a marked decrease in cholesterol levels with a significant increase in high-density lipoprotein.

Total cholesterol and triglyceride levels were found to be significantly $(\mathrm{p}<0.01)$ increased in the standard treated diabetic group (Alloxan + glibenclamide $10 \mathrm{mg} / \mathrm{kg}$ ) in comparison with the control group. Administration of chloroform and ethyl acetate extracts and glibenclamide recovered the diabetic induced changes and decreased the level of lipids (cholesterol: $144.33 \pm 38.70,99.67 \pm 1.53$ and 141.67; triglycerides: $75.00 \pm 1.00,67.83 \pm 0.76$ and $62.83 \pm 1.04$; LDL-c: $71.23 \pm 0.25,68.20 \pm 0.26$ and $57.93 \pm 0.70$ respectively) with an increase in HDL-c $(48.21 \pm 0.26,36.47 \pm 0.42$ and 34.80 \pm 0.72 respectively) when compared to the untreated diabetic rats.
In this study, there was a significant decrease in hemoglobin levels down to the near normal range in diabetic animals treated with methanol, chloroform and ethyl acetate extracts of Clitoria ternatea flowers. Oral administration of the methanol, chloroform and ethyl acetate extracts were an effect on hemoglobin, by preventing its elevation and was found to be effective in restoring hemoglobin to normal levels.

\section{CONCLUSION}

In conclusion that this study, increased level of glucose was observed in alloxan diabetic rats that may be due to insulin secretion. The flower extracts of Clitoria ternatea tested for antidiabetic activity as it significantly lowered the serum glucose levels and increased the body weight of diabetic rats. Clitoria ternatea scientifically justifies the use in the folklore remedies for anti-diabetic activity.

Thus the study ascertains the value of plants used in ayurveda, which could be of considerable interest to the development of new drugs.

\section{REFERENCES}

Alarcon Aguilar FJ, Roman Ramos R, Perez Gutierrez S. Study of the anti-hyperglycemic effect of plants used as anti-diabetics. Journal of Ethanopharmacology, 1998; 61: 101-110.

Allain CC, Poon LS, Chan CS, Richmond W, Fu PC. Enzymatic determination of total serum cholesterol. Clinical Chemistry, 1974; 20: 470-475.

Anand SP, Doss A, Nandagopalan V. Anti-bacterial studies on leaves of Clitoria ternatea Linn. - a high potential medicinal plant. International Journal of Applied Biological and Pharmaceutical Technology, 2011; 2(3): 453-456. 
Aruna RV, Ramesh B, Kartha VN. Effect of beta carotene on protein glycosylation in alloxan induced diabetic rats. Indian Journal of Experimental Biology, 1999; 37(4): 399-401.

Bowers LD. The role of various factors in determining specificity. Clinical Chemistry, 1980; 26: 551-554.

Debra Manzella RN. Kidney disease in diabetes. 2008. http://diabetes.about.com/od/preventingcomplications/p/kidneydisease.

Fawcett JK, Scott JE. A rapid and precise method for the determination of urea. Journal of Clinical Pathology, 1960; 13: 156-159.

Friedewald WT, Levy RI, Fredrickson DS. Estimation of the concentration of low-density lipoprotein cholesterol in plasma, without use of the preparative ultracentrifuge. Clinical Chemistry, 1972; 18: 499-502.

Ghosh MN. Fundamentals of Experimental Pharmacology. $3^{\text {rd }}$ edition, Hilton and Company, Kolkatta, 2005; 190-197.

Ginsberg HN. Lipoprotein physiology. Endocrinology

Metabolism Clinical North America, 1998; 27: 503-519.

Goth L, Eaton JW. Hereditary catalase deficiencies and increased risk of diabetes. Lancet, 2000; 356: 1820-1821.

Jelodar G, Mohsen M Shahram S. Effect of walnut leaf, coriander and pomegranate on blood glucose and histopathology of pancreas of alloxan - induced diabetic rats. African Journal of Traditional, Complementary and Alternative Medicines, 2003; 3: 299-305.

Lowry OH, Rosebrough NJ, Farr AL, Randall RJ. Protein measurement with the Folin phenol reagent. Journal of Biological Chemistry, 1951; 193: 265-275

Mansour HA, Newairy AA. Amelioration of impaired renal function associated with diabetes by Balanites aegyptiaca fruits in streptozotocin induced diabetic rats. Journal of Medicinal Research Institute, 2000; 21: 115-125.

Mukherjee PK, Kumar V, Kumar NS, Heinrich M. The Ayurvedic medicine Clitoria ternatea - From traditional use to scientific assessment. Journal of Ethanopharmacology, 2008; 2: 832.
Muller PH, Schmulling RM, Liebich HM, Eggstein M. A fully enzymatic triglyceride determination. Journal of Clinical Chemistry and Clinical Biochemistry, 1977; 15: 457- 464.

Payne C. Complementary and integrative medicine: Emerging therapies for diabetes. Diabetes Spectrum, 2001; 14: 129-131.

Reid R, Sinclair DF. An evaluation of a collection of Clitoria ternatea for forages and grain production. Genetic Resources Communication, 1980; 1: 1- 8 .

Roeschlau P, Bernt E, Gruber W. Enzymatic determination of total cholesterol in serum. Zeitschrift fur Klinische Chemie and Klinische Biochemie, 1974; 12(5): 226.

Tian YM, Johnson G, Ashcroft JH. Sulfonylureas enhance exocytosis from pancreatic b-cells by a mechanism that does not involve direct activation of protein kinase. Diabetes, 1998; 47: 1722-1726.

Trinder P. Determination of glucose using glucose oxidase with an alternative oxygen acceptor. Annals Clinical Biochemistry, 1969; 6: 2427.

Wilson BW. Automatic estimation of urea using urease and alkaline phenol. Clinical Chemistry, 1966; 12: 360-368.

\section{How to cite this article:}

Manivannan Rajamanickam, Prabakaran Kalaivanan, Ilayaraja Sivagnanam. Evaluation of Anti-oxidant and Anti-diabetic Activity of Flower Extract of Clitoria ternatea L. J App Pharm Sci, 2015; 5 (08): 131-138. 